\title{
The Impact of Technology on the Spiritual Health of University Students: A Case Study of Africa University
}

\author{
Ali Wantimba, Mazvita Machinga Ph. D \\ Africa University Fairview Rd, Old Mutare, Mutare, Zimbabwe
}

\begin{abstract}
Technology has prompted diverse thoughts concerning its impact on the spiritual health of university students and it's urgent that effective measures for better use are identified. This study aimed at examining the impact of technology on the spiritual health of university students. The study was conducted at Africa University; a United Methodist Related Institute located in Mutare Zimbabwe. A qualitative research design and a case study methodology were employed. Data was collected using questionnaires and participant observation, and data coding was employed to analyse collected data. After the presentation and analysis of the findings, the results showed that technology was a very essential instrument for the growth of the spiritual health of university students, it also showed that university students can balance the impact of technology on spiritual health. But it required self-control, personal morality and self-discipline on the side of the university students if it was to produce positive results that could benefit university students spiritually. However, watching of pornographic material proved to be a big hinderance to the spiritual health of university students as they used technology. Technology was also seen as a medium that could foster a faithful relationship between God and Humanity. Technology was understood to have brought salvation closer to humanity, through the abundant spiritual information online, and online platforms like religious websites. In other words, technology could easily lead university students to God's kingdom if they used it in a proper way especially through sharing religious information. A model for technological use was formulated from the study which was developed based on the idea of technological Sabbath by (Heschel, 1951), the model is the Techno Spiritual Retreat (TSR) and the Awareness, Breathe, Choice and Doing (ABCD) formula.
\end{abstract}

Key words: Techno spiritual retreat, ABCD formula, Spiritual health, Technology, pornography.

\section{INTRODUCTION}

A ccording Murapa (2017) the Africa University Clinician, the number of students who engaged in sexual intercourse while on campus was growing rapidly. And many of these students were experiencing sex for their first time. Most students reported that they got their sexual partners through their social media pages as compared to face to face approach. Also, some students were sexually abused by their peers using social media through cyber bullying. Additionally, Muchanyereyi (2019) the Africa university Chaplain in one of her sermons, was very much concerned about the reduced number of students attending church services as many preferred to stay in their rooms to revise their books than attending Wednesday and Sunday church services. According to Reverend Muchanyereyi, most university students rarely practise what they listen to in churches as they consider such advice not relevant to their lifestyles. According to her, technology (social media) provides the trend of behaviors and fashion that university student follow, neglecting whatever is taught to them in the churches. The Africa University Dean of Students then Dr Mazvita Machinga in 2018 cautioned Africa university students to remember that Africa university is a church founded and related institution that expects its students to take christian principles with paramount value. Yet all these seem to fall on deaf hears, as technology social media in particular continuously controls the behaviors of Africa university students. Being a student of Africa University for over 4years now, I have also observed how my fellow students use technology both in good and bad ways. I have observed a decreased participation in religious activities of many students due to social media use.

Technology has become part and parcel of university students' everyday lives, filling a substantial portion of the constructive minutes and hours of their days (Jechoutek, 2004). Rajvanshi (2016) reported that, technology has been on the increase in the recent centuries and this has triggered mixed opinions to many aspects of the human society. He went ahead to suggest that, the spiritual health of university students is one of aspects of life that has been greatly affected. "Especially taking into consideration that university students use technology than any other group of people" (Marma, 2018, Para.2). "Some university students' spiritual life has been totally diverted by technology to the extent that some even think that they can accomplish anything with technology, thus despising the need for divine intervention in their lives" (Barna Group, 2016, para.4). However, at the same time technology has moulded the spiritual life of some university students. Thus, becoming faithful believers of God.

According to Allen (2019) technology affects the way individuals communicate, learn, and think and helps the society determine how people interact with each other on a daily basis. Allen states both positive and negative effects of technology on thedailylives', spirituality included. According to him, we are living in an era where technological advances are common. However, with technological advances, there's a downside to it all. Allen notes mobile technology which he 
thinks can decrease communication and relations between people, creating less personal time, where university students don't find enough time for themselves and their friends, which in turn too affects their relationship with God.

"The evolution of technology has taken place at an unprecedented and unexpected rate so much, that it has been dubbed the second industrial revolution" (Rajvanshi, 2016, para.6). In his analysis Rajvanshi (2016), states that, "where it took 75 years for a technology such as telephone to reach 50 million users, it took the World Wide Web barely four years to reach the same number of users". Scott (2016) stated that, from 2004 to 2005 the number of e-mail users worldwide increased by $15 \%$ to 651 million and the daily traffic constituted 76.8 billion messages, and university students constituted most of these numbers. According to a new report from Cambridge International Education (2018), which is based on an online survey of nearly 20,000 students (ages 1235) and teachers from over 100 countries. The survey found that use of technology in schools worldwide continues to grow, with 48 percent of students reporting they use a computer in the classroom. Forty-two (42) percent use smartphones, 33 percent use interactive whiteboards and 20 percent use tablets. Although the way spiritual health is affected by technological use varies from student to student but $52 \%$ presented negative impact.

According to Leah (9th Feb 2018) most university students and youth today can't imagine a world without technology and youth seem to be deeply interconnected today, where one harmful effect of technology is likely to affect a web of youth. The BarnaGroup (2018)reported that nearly half of American teens $(48 \%)$ spend their free time on social media or texting with friends. This number rises by a significant margin every year, according to statistics from the Pew Research Center. In 2005, just 5\% of American adults used Facebook, Twitter, or Instagram. By 2011, that share had risen to half of all Americans, and today, $69 \%$ of the public uses some type of social media.According to Leah (2018) because social media allows users to present the best versions of themselves, university students are susceptible to falling into the temptations of self-glorification, comparison, discontentment, and idolatry.Thus, affecting the spiritual health of university students. Dr. Douglas Groothuis, Professor of Philosophy at Denver Seminary, warns that continued smartphone use and the constant seeking of applause causes college students to ignore their finitenessas humans instilling in them a subconscious desire to become infinite like God.

Additionally,Groothuis (2018)wrote about the continued portrayal of violence, sex, and drugs/alcohol on social media, stating it as one of the biggest factors which adversely affects the behavior of university students. A 2012 study from Psychological Science also found that the more youth were exposed to sexual content in movies, the earlier they started having sex and the likelier they were to have casual, unprotected sex. Thus, going against the biblical principles of not having sex before marriage. Another study found that youth who view media violence are more likely to have increased feelings of hostility, decreased emotional response to the portrayal of violence and injury that lead to violent behavior through imitation. Violence in the media has been increasing and reaching proportions that are dangerous," said Emanuel Tanay, MD, a retired Clinical Professor of Psychiatry at Wayne State University and a forensic psychiatrist for more than 50 years.

Africa university students, I may as well call, "the e-austudents" are so much into technology to the extent that technology is no longer a luxury but a necessity. In fact, according to R. Fotsin (personal communication 2019, February, 18th) the Africa university ICT director showed that, at Africa University 9 out of 10 students own a computer and a smart phone at the same time, which are able to connect to the internet. And 10 out of 10 students access unlimited internet for at least five days in a week.It is therefore clear that any Africa university student who does not go digital, in other words who cannot manipulate technological devices is at a risk of being side-lined by his peers and being labelled an "analogue student". This technology which I may as well call, "the e-life" has not only affected Africa university students' daily life relationships with each other but also their religious life both positively and negatively.

Darius and Grand (2004) stated that, since the advent of modern society in the 18 th century, technological progress has determined and defined many of our attitudes relating to happiness, power and our sense of value. In other words, technology has shifted from being a tool aimed at assisting us in our creative earthly roles and indeed has become a mediator of self-awareness and an end unto itself. For many years' technology was perceived as intrinsically relevant, but more and more people begin to question whether technology can be relevant especially when it comes to the building of one's spiritual life and the community as a whole. While some people even wish to do away with the idea of technology altogether and return to a lifestyle of simplicity, other people keep on praising technology to a level where by they cannot do without it because it has become part and parcel of their lives. At Africauniversity, students fall in both these two categories and that's why I carried out this research in a university setting.

Carr (2010) defined spiritual health as the possession of universal and unchanging values in their highest and purest forms such as truth, right actions, peace, and non-violence, more specifically the love of God and neighbour. "Spirituality existed long before the coming of technology, but the later phenomenon cannot be denied because of the impact it has posed to the population" (Herzfeld, 2002, p106). The fact that it has come with a lot of positive and negative connotations, has pushed many researchers to investigate on how it can properly be incorporated in our spiritual world. During the inception of technology in the 1960s, most people lacked love and enthusiasm towards its use, but as more improvements around the 1980s came, people became more enthusiastic 
towards the use of technology, (Banks, 1983).There has been a lot of research about the impact of technology on the spiritual health of university students, but most of the researchers examine the negative impact of technology on the spiritual health. The other issue is that most researchers like Albert Borgmann, Erazim Kohak, Neil Postman and Rosie Perera looked at the effects of technology on spirituality in general. No one has exactly come up to focus on university students. However, it is very important to understand that a university setting is very different from a society setting.

The distorted worldview of our lives can be primarily blamed on our distorted view of our technologically dominated life says (Borgmann, 2014). Borgmann argues that technology has distorted our sense of value and distanced us from our world and our sense of place in our village and universe. We have shifted from values that build on customs and traditions to ones that focus on goals and ambitions towards the future, our life is about an obsession with adjectives such as 'more, larger, prosperous, efficient, easy' says Borgmann.Rajvanshi (2016) stated that, the consequent disability that prevents us from looking inwardly is probably technology's biggest challenge for the spiritual life. Technology depicts itself in our lives though our surface exposure of consumption in public and its real effect sticks to us through various manifestations of personal anxiety and dysfunction.

There is limited literature regarding technological impact on the spiritual health of university students. Also, most of the literature available talks about technology and religion or the church not specifically relating to university students. In additional the available literature has some gray areas that require more investigations. Most scholars have concluded that technology has more negative impact on the spiritual health but leaving without examining the positive side of technology. Therefore, this research has also clarified on what I see asa misconception that technology negatively affects the spiritual health of university students.

\section{Statement of the Problem}

There is a reduction of student participation in religious activities leading to engaging in risky behaviors that end up affecting their spiritual life. Personal and social behaviors of university students are rapidly changing as technology use increases. While some students have used technology for good aims, thus, growing spiritually, other students use technology for bad aims, thus, damaging their spiritual life. In addition, the positive impact of technology to the spiritual health of university students have not been given much attention in the previous studies. This has instigated a fallacy on how people view technology in relation to spiritual health. How can technology positively contribute to the growth of the spiritual health $(\mathrm{SH})$ of university students. In other words, how can university students positively utilize technology for the growth of their spiritual health. This study has established a theory or a model on how technology can become a handmaid of spiritual health. I believe technology is capable of positively contributing to the growth of the spiritual health of university students and the community at large. Look at the mass communication of spiritual messages through print, radio, televisions and more broadly the internet which reaches all corners of the world. These instant spiritual messages have provided a wide range spiritual experiences enabling the growth of both the mind and love for God and neighbour. Therefore, this study has elaborated ways of how technology can positively be utilized that will aid the growth of the spiritual health of university students.

\section{Research objectives}

a. To find out how technology can be used for the good of the spiritual health of university students.

b. To identifyhow technology impacts the growth of the spiritual health of university students.

c. To investigate the factors influencing university student'sspiritual growth as they use social media.

\section{Research questions}

a. How can technological use by University Students be used for the good of their spiritual health?

b. How does technology impact the growth of the spiritual health of university students?

c. What factors are influencing university student's spiritual health as they use technology?

\section{Inclusion criteria}

This study was limited to the population of Africa universitywhich consists of both lecturers and students, the study however focused on the students and only students who were studying either the Bachelors of divinity or the Bachelors of computer science. Age was not considered as a factor for inclusion.

\section{Exclusion criteria}

All students outside Africa University community and lecturers were not eligible to participate in this study and also students doing other programs, not considered in the sample were not part of this study.

\section{REVIEW OF RELATED LITERATURE}

Conducting this research on the impact of technology on the spiritual health of university students does not mean that nothing has ever been done in the specified area of study. A lot has been done especially researches concerning the impact of technology on spiritual health or spirituality. However, not on university students and specifically at Africa university. It was therefore, important to find out what had been written concerning technology and its impact on the spiritual health by other researchers. Review of related literature has clearly complemented the need for a research. Reading the previous studies was very essential to me because it provided some scientific facts which served the study.

According to Kiprono (2014) it is important to mention at the onset that technology when rightly used becomes a powerful missiological tool and a vital instrument in enhancing the 
advancement of the Kingdom of God. He notes the worldrenowned televangelist Billy Grahams' ministry which has led many young people to the saving knowledge of Jesus Christ. According to him many people have through technology had unlimited access to biblical and devotional materials from the internet. However, it is noteworthy to mention that false and misguided teachings have become rampant and are escalating like bush-fire via internet and other social media. For this, many universities have been negatively indoctrinated and radicalised in extreme situations. On the same note, the Christian faith in many ways has been post modernized. This effect is conspicuously evident in the lives of the university students, especially in matters of faith and practice, and most specifically to students who are masters of technology, social media in particular. Due to these, scepticism has taken roots in university students lives. The availability of diverse "Spiritual Materials" has exposed them into different versions of faith as a result, confusion prevails in their spiritual life.

Emoavwodua (2018) recently wrote that, there has been an increase in the call for a solution to the 'technology menace' as he termed it. This menace according to him, is seen in the increased addiction of technology users and other internet products; and the exploitation of internet users by internet companies. University students being the prime users of technology are highly affected and in all aspects of their life, spirituality included. However, Emoavwodua did not look at those responsible for the technology menace, which would help to provide solutions.

As a Christian, Guardini (1994), laments the loss of a more contemplative approach to life that the growth of technology has brought. He states that, the will to technology has left us incapable of independent judgment, of making wise decisions about the technology we use, it has proliferated shoddy workmanship and dulled our minds. In my view, Guardini is concerned about losing our old life that was based on the laws of nature, too simple and straight forward to becoming virtual citizenswho despise divine help. Some university students think technology can accomplish anything for them and all the rest is labelled old fashioned. However, Guardini neglects to look at what technology can do to improve humanity and a vast resource that it provides that can help university students grow spiritually. There is therefore a need to balance the discussion when looking at the impact of technology on the spiritual health of university students.

Ellul narrates that, the worst disease of technology now is probably the ideology of Technological Heroism, to which more and more people willingly cause large-scale effects that they do not foresee and that they cannot control (Ellul, 1997). In addition to Ellul's words, I would say, we have less time for healthy meals, exercise, and relaxation, just with the aim of becoming technological experts. The aim to become technology experts has caused a greater damage to the spiritual life of university students. However, like Guardini, Ellul also does not look at how the technology heroism that may be attained by students can help them grow spiritually and also help other people improve their relationship with God. I do not think technology heroism only leads to dangers, because we have seen technology experts develop many spiritual resources on internet like meditation applications, bible applications, online churches and others. These can play a key role in the spiritual development of university students.

Buckingham and Domaille (2002) showed that, interpersonal relationships have been affected negatively, as "the time needed to genuinely deepen relationships, rather than to simply catch up with others, is not allowed," due to the fact that people see texting through WhatsApp, Instagram, Facebook etc simpler than talking to the person face to face. Yes, this true, interpersonal relationships are greatly affected with the presence of technology, yet these relationships are a key to the relationship of people with God. However, technology also in many cases may develop self-esteem of certain individuals thus developing interpersonal skills.

Actually, there is almost a worship of technology today in many quarters of the world, it has become an end onto itself, not merely a means to an end. "We have trusted technology for our deliverance instead of God, we are making it into an idol" says (Thoreau, 2000, p 345-401). In other words, even simple things like going next door to greet your neighbour is now difficult all thanks to technology, someone prefers texting. To summarize Thoreau's words, humanity has transformed technology into a god. In other words, while people in the ancient world worshiped animals and heavenly objects as their gods, the modern people seem to be worshiping technology as their god, but they seem unaware.

We have become trapped within our own technological inventions, the ones that have been created as a response to our unending drive for more(Olthuis, 2001). I think Olthuis is of a view that, the child we gave birth to has turned against its own parents. According to Wendell (2002) although we may at times get a glimpse of the spiritual and ethical costs related to our ways through technology, we have still become dependent on the very same technology that was meant to set us free. Thus, negatively affecting our relationship with God. It is now clear from the above that, we have failed to balance the impact of technology, for our benefit spiritually. In my own view I would say, the child has disobeyed its parents, now the parent needs to put some disciplinary measures, to correct the child back to the right path, if he is to benefit from it.

Olthuis (2001) still in his writings showed that, technology has become a prison for human spiritual life. In other words, technology seems to have become the master to our spirituality controlling our view and relationship with God. I would partially agree with Olthuis, especially when it comes to how university students are adapting to new technology and the concept of globalization to the extent that all their reasoning is influenced with what they see in technology. However, there is still a certain degree of ideological independence that people have while using technology. Meaning technology cannot fully control humanity but 
humanity always have an upper hand and can resist the temptations of technology.

According to Christian (2012) even though technology is broadening our abilities in some ways, it is also creating a culture where we are limiting the time we allocate for intelligent questioning and reflection upon our daily lives and our relationship with God, to a narrow and often abbreviated form of knowledge and this damages us spiritually.For him, even though technology has some positive impact, it's more of a foe to spiritual health than an acquaintance, which should be rejected. I totally disagree with Christian, basing my argument on the variety of spiritual resources available for use of spiritual development for anyone. Also considering the modernity of today, where everything has been digitalised an analogue christian would face challenges accessing Godly resources.

Steinhart (27th, September 2018) wrote exclusively about spirituality and technology, he stated that the two have an uneasy relationship. According to him, many people often think that technology and spirituality are opposed and that the more you're into technology, the less spiritual you become, even going further to think that technology is anti-spiritual andat the extreme, they think of technology as evil or dehumanizing. However, recently more and more people start to believe that technology and spirituality belong together, and that they help each other and make each other stronger. I strongly agree with the assertion by Steinhart,spirituality and technology should be looked at like fraternal twins, who complement each other whenever necessary. Even though technology has affected the spiritual health of university students especially through limiting interpersonal relationships as says Buckingham and Domaille (2002). Technology has too been very munch resourceful when it comes to providing religious materials as Borgmann wrote.

Behav (2017) looked at some of the factors that greatly affected the spirituality of university students as they used technology; he noted Cyberbullying, when people used technology to embarrass, harass or bully other people, this include posting mean or untrue statements, making fake online profiles intended to embarrass people, sharing embarrassing photos, and more. He also noted trolling where people deliberately tried to start arguments or to upset people on the internet, often causing considerable distress. Isolation was another factor noted by Behav where people spent too much time online, dedicating less time on face-to-face interactions with family and friends, this according to him created barriers and contribute to a sense of spiritual decline. Behav also noted that, students posting inappropriate pictures or content online leading to Inappropriate relationships with strangers greatly affected their relationship with God.

Lyb (2011) was much concerned about social media use, he writes that there has been a shift away from expressing our self-identities, towards constructing facades based on the answers to these questions: "How will others look at me?" and "How can I ensure that others view me positively?" According to Lyb, the goal for many people now in their use of social media becomes how they can curry acceptance, popularity, status, and, by extension, self-esteem through their profiles and postings. It is clear to him that, Self-awareness and selfexpression has given way to impression management and selfpromotion.

In my view, it seems people are more concerned about identities they would like to have or that they want people to see rather than who they really are. This has led to selfexaltation and independence from God, thanks to technology. People are therefore using technology to promote and market the identities they want people to see. In the process they neglect their naturally created beauty, this is all against the principles of God.Paradoxically, in striving for approval by our social world, we unwittingly sacrifice our true selfidentities and shape our identities to conform to what the digital world views as acceptable identity. And, in doing so, we relinquish the specialness that we hold so dear and given to us by God.

Archibald (2013) continues in agreement with Olthuis and Guardini in thinking negatively about technology use on spirituality, when he says, science has documented that technology use is changing how our brain functions. According to him, its use creates new neural pathways and causes cognitive overload in the area of our brain that controls decision-making, impulse control, attention, focus and shortterm memory, this may cause changes in how people think about God. He also noted that, digital media technology use encourages bad habits that affect our focus, productivity, busyness, reading skills and our personal interactions" (Archibald, 2013). Additionally, technology completely turns you into a new virtual creature independent of the laws of nature, thus destroying your spirituality. I agree with Archibald partially because when human brain is affected by technology, especially by the distracting nature of technology, this affects spiritual meditation, prayer and contemplation. The changes in our reading habits affect our study of Scripture, and storing God's word in our hearts. Changes in how we interact with each other affect worship and fellowship, as well as how we relate to God.

Makayla, C.S (1996) writes that, looking at the computers, streaming TV's, tablets, readers, game consoles, smart phones and smart watches, these give us an ever-present portal to emails, scripture alerts, texts, calendar alerts, and the abundance of the World Wide Web, with its social media sites, news, blogs, information, music, and games, thus practising the presence of technology than the presence of God.However, these at the same time provide a platform for spiritual formation depending on the person using them. Borgmann (2014) line with Makayla showed that, the surface of these troubling days is generally attributed to the swiftly advancing technologies. According to Borgmann technology has enabled humanity shift from values that build on customs and traditions to ones that focus on goals and ambitions towards the future. I agree with Borgmann, in the sense that 
people becoming more ambitious has caused people to not use a reflective mind as they use technology thus affecting them spiritually. Ambitions for material gains now leads the production of new technologies rather than spiritual gains.

According to the report from Geneva Business School (10 August 2020) technology and the entrance of eCommerce is seen to eliminate manual labour in the past, but people don't always recognize how these innovations are making them lazy, too. People no longer need to run errands anymore; we literally can press a button and have most of our first world problems solved in an instant. I totally agree with the above assertion because, this laziness has not only affected the industrial world, but also the spiritual world, where most youth now prefer attending churches online rather walking a kilometre to the church building.

Seth (2018) in his study on "Is Technology Morally Neutral or a Moral Peril?", he elaborates that because digital interaction is so ubiquitous and requisite to our daily life, it is difficult to step away and examine our relationship with it. According to Seth, people are too pervasively engaged with our digital technology to think self-reflectively about how it is affecting their lives, relationships and culture at large, much less how it is affecting our spiritual life. Yes, I agree with Seth, because as people use technology, they forget to think about what it is doing to their brains, hearts and souls. In other words, they are much more likely to be practicing the presence of the smartphone than the presence of God. People are much more likely to be tuned into the blessings of convenience, comfort and control than the blessings of God.

Legg (2020) was concerned about the overuse or dependence on technology which he thinks may led to adverse psychological effects, including isolation where technologies designed to bring people together, act oppositely as they distance people in the real sense. Legg refers to a 2017study by Pew Research Centre on young adults aged 19 to 32 years which found that people with higher social media use were more than three times as likely to feel socially isolated than those who did not use social media as often. However, I think isolation may present a double-sided effect to the spiritual life of an individual, it can either develop spirituality through isolative meditation and weaken it through affecting interpersonal relationships.

The authors of a 2016 systematic review Trusted Source discussed the link between social networks and mental health issues, such as depression and anxiety. Their research found mixed results. People who had more positive interactions and social support on these platforms appeared to have lower levels of depression and anxiety. However, the reverse was also true. People who perceived that they had more negative social interactions online and who were more prone to social comparison experienced higher levels of depression and anxiety. I believe that conditions of depression and anxiety can also affect the spiritual life of an individual.
The researchers I have presented so far, seem to see on paramount value in technology when it comes to the growth of spiritual health. They are all of a view that technology has more distanced us from the kingdom of God than preparing us to receive God's kingdom. Most encourage people to stay away from technology if at all they want to live in the presence of God. But can technology have some value in it, that can help university students or the community at large grow spirituality, I will be considering some other researchers in the coming paragraphs of the literature review below.

Kohak and Borgmann, along with Heidegger, the most philosophical of the writers in the area of technology, are equally profound in their different insights. In my view, they have the most compelling answers to this technologyspirituality tension of all the authors I have considered. Like Banks and to some extent Guardini, they both suggest ways of preserving something of transcendent value in the midst of technological society, without totally rejecting technology.Neil (1992) suggested that, every technology is both a blessing and a curse, "all technological change is a Faustian bargain". This means that for every advantage a new technology offers, there is always a corresponding disadvantage." In short, "culture always pays a price for technology. Neil's ideas can be encapsulated in a quote from one of his lectures: "The best way to view technology is as a strange intruder, to remember that technology is not part of God's plan but a product of human creativity and hubris, and that its capacity for good or evil rests entirely on human awareness of what it does for us and to us" (Neil, 1996, 78). I fully conquer with Neils' views about technology, for I believe technology has a substantial contribution to the spiritual development of various individuals. Basing my argument on Makayla's' study, a lot of products are provided by technology that embed in them a resource of spiritual material which when used properly can bridge the gap between God and humanity, thus aiding individual spiritual growth.

Monahan (2009) a professor at Liberty Baptist Theological Seminary, argued that both the positive and negative influences of technology have made our students more informative yet less personally intimate. He argues that, the shift of personal interaction presents a challenge to the cognitive development and spiritual formation of all students. According to Monahan, great spiritual teachers down through the ages have understood the state of technology, but awareness of the role that technology may play in the development of individual's imagination, and of the role that inspiration may play in individual's spiritual development has been longer in coming. I fully agree with Monahan because, the modern progress of technology not only has intensely influenced nature, but also has penetrated all fields of social life, with ever increasing impact on society and its development. This has intensely influenced the development of the human being himself, thereby making a deep notion on the interaction between humans and nature and on 
interpersonal relations, in a word on the comprehensive development of contemporary human life.

According to Borgmann (2014) it seems that we shall no longer use technology to assert our independence from God, but rather we will bring it as an offering to glorify God (Rev 21:24). Borgmann says technology has to be transformed in such a way that it has no negative side effects. Yes, I believe technology can be used to glorify God in many ways especially if we use it properly, but I disagree with Borgmann's view of making technology without negative effects, because I believe the negative effects of technology depend on the people who are using it. So, with the over ambitious people of this modern day, where desire or goals are profit oriented; it becomes difficult to completely eliminate the negative side-effects of technology. Borgmann taken as one of the greatest scholars in the area of technology, does not also agree that technology is totally bad and should be rejected, but is of a view that we can use it for the glorification of God, and thus growing spiritually. Therefore, we are to work towards realization of the good potential of technology and minimize its harmful consequences, to master it for building personal and community spirituality rather than succumbing to its anti-social behaviours, and enhance its capacity to be functional, beautiful and appropriate rather than ugly and rapacious.

Indick (2012) wrote that, spirituality is not deterred or inhibited by technology, he holds a view that technology holds a great potential to be of help to our spiritual health. In other words, it is technology that is bringing wonderful and seminal changes to the quality of our spiritual lives. According to Indick, you are able to read these very words because of technology, and the dimension of knowledge both spiritual and secular has taken different dimensions thanks to technology. Indick is right, there is no way we can deny the good that technology has done for human spiritual, even though other christians still consider it a foe of human spirituality.

According to the freedom lab (2018) the amount of material on the internet regarding spirituality in form of texts, audios, videos and even active internet websites is just awesome and makes spiritual information accessible. Gone are the days when one needed to go to the library to get some nuggets of spiritual wisdom buried in ancient books. Technology makes it easy for you to download those texts while sited comfortably and you will acquire a lot of spiritual knowledge. The same is also true for spiritual counsel, (Prabuddah, 2015). People don't need to physically look for their pastors and counsellors, a single text would be enough.

Like Guardini and Borgmann, Banks sees that, the march of technological progress is not going to stop, so we must learn to pace our lives well in the midst of it, and allow time for a healthy spiritual life (Banks, 2016). Much of what Banks says seems like common sense, but it is a sense that is easily obscured by the culture we live in. It is good to be reminded of these things. Actually, there is no chance to avoid technology because of its increasing benefits and the speed at which it is evolving, so we must train ourselves on how to live in a hyper-connected world. Like Heidegger, Borgmann in his earlier works rejects the idea that technology is an autonomous pernicious or evil force, (Borgmann, 1997). Heidegger brought us to see that technology, which is characteristically instrumental, is in fact a way of revealing. Heidegger quotes German poet Hölderlin: "But where danger is, grows the saving power also" (Heidegger, 1977). In other words, the essence of technology must harbour in itself the growth of the saving power. And it is all upon humanity who is the real inventor of this technology to also discover the saving power. This is a very strong contribution to the technology-spirituality tension, because some people are failing to use technology appropriately because of their greed or wanting more. People have the natural capacity to decide on how to use technology but most people have not come to grips with that reality.

Gigli et al (2001) accuse technology of controlling human life and controlling any spiritual development of individuals. According to the above authors, by increasing the limitations on human life and teachings, technology becomes sovereign over their social life. In sophisticated industrialized countries for instance, technologization places excessive prominence on material outcomes, thus relatively reducing the function of spiritual values. For the young people, this encourages their indulging in material enjoyment while putting aside the spiritual search; it urges paying great care to technological sciences while disregarding the level of humanities. Additionally, globalization of technology brings opportunities to expand individual perspectives and add more equivalent access to information, but it also intimidates religious identification and values. It is therefore, urgent that societies both look after minors and empower them to assess their own media milieus, as spelled out by the United Nations Convention on the Rights of the Child and progressively more by media educators and experts around the world.

According to Rosie (2004) we are called to exercise stewardship over technology and use it to accomplish God's redemptive will for the world in this "already but not yet" age. One way that we can maintain an eternal perspective and protect our spiritual life from becoming suffocated by technology is to observe the gift of Sabbath (Heschel, 2005). To always rest in our engagement with technology. A foundational truth for thinking about technology and creation is that when God created the material world, he pronounced it good, indeed "very good" (Gen 1:31). God demonstrated himself as "the arch-technophile and the ultimate enabler of human technology" when he "majestically displayed his techne by shaping the universe's materials into all the wonders, both inert and living, that we now observe." (Rosie, 2004). I therefore want to argue that, God in the very beginning knew that technology would be used by his people to find his ways. Those who use technology for greedy gains are on the wrong route and need to rethink their purpose of life. 
Borgmann (2004) proposes a reform of technology which "is neither the modification nor the rejection of the technological paradigm but the recognition and restraint of the pattern of technology so as to give focal concerns a central place in our lives. By focal concerns he meant the key indicators in our relationship with God and also the love of our neighbours.People are to go back and start focusing on the key principles and responsibilities of God's intention on creation. Technology in itself is not bad; it has brought us much good, and is authentic to human existence. But in the midst of it, we have forgotten who we are. We feel alienated in the "anonymous world; we try to resolve the tension by convincing ourselves that we, too, are machines. People lose valuable time while on phones and computers, accidents happen while concentrating on sending a text to someone, most importantly interpersonal relationships become less effective.

\section{THEORETICAL FRAME WORK}

My theoretical framework was based on the idea about, "Technology Sabbath" (TS), from a dissertation on technology and Christian spirituality by Rosie Perera written in 2004. Rosie quotes this idea from an article about a "Technology Sabbath" that took place at Seattle Pacific University written in a book by Abraham Joshua Heschel, the Sabbath, in 1951. In this article a group of 300 students from two of the residence halls voluntarily gave up the nonessential use of technology (apart from class work) for a week, so they could focus on friendships and faith. They avoided television, video games, online chat rooms. They walked down the hall to talk to a friend instead of using the telephone or e-mail.

The experience was eye-opening for most of them. They rediscovered the joy of simply spending time together the oldfashioned way. The solution of mankind's most vexing problem will not be found in renouncing technology, but in attaining some degree of independence of it, the welcoming of a Sabbath is one way to do that (Heschel, 1951). On the Sabbath we live, as it were independent of technology: we abstain primarily from any activity that aims at remaking or reshaping the things of technology.

But I don't see the idea of a technology sabbath fully successful while working alone to harmonise technology and spiritual life. This because some people take their technological devices as necessities which they have to use 24/7hours, to others that's their business if they don't use them then nothing to eat. Therefore, not everyone will buy the idea of a technology sabbath. I therefore differ in suggestion, saying that we also need to look at and screen the information obtained while using technology and see how it can be beneficial or dangerous to the growth of our spiritual health. And also, people need to be aware of how technology has distracted them from their interpersonal life. I therefore developed the Technological Sabbath idea by Heschel to make more relevant. And this was taken to be the departure point for this research study.

\section{METHODOLOGY}

A Case study approachand a qualitative methodology were used to carry out this study because the researcher was interested in learning the details of the participants behaviours, needs, desires, routine activities, emotions and personal characteristics, and also based my conclusions on lived experiences. I used a qualitative research design because it views reality as subjective and attains its knowledge through lived experiences and it is mostly associated with words, language and experiences rather than measurements, statistics and numerical figures. And I also, wanted to develop an understanding of student's opinions about the use of technology in the growth of their spiritual health. A qualitative-case study research design helped me to generate an in-depth account that presented a lively picture of the research participants' reality about the understanding of technology as a handmaid of spiritual health. A qualitative research design gave me a unique depth of understanding which is difficult to gain from a closed question survey. Participants were freely allowed to disclose their experiences, thoughts and feelings without constraint. A qualitative research design also offered a dynamic approach to research, where I had an opportunity to follow up on answers given by participants in real time, generating valuable conversation around a subject something which isn't possible with a structured survey.

\section{Population}

This study described population as all people that fall in the category of concern of the study area. The population of the study was all the students of Africa University. The total population was 2682 students, these were all students of Africa university; 1071 students slept on-campus while 1611 slept off-campus. Data collected was from both on and off campus students. The population was divided into these two groups to make sure that data collected had diverse opinions considering the fact that off-campus students spent less time online as compared to on-campus students.

\section{Sampling procedures}

A purposive or selective sampling method was employed, whereby I only chose participants who would offer in depth and detailed information about my area of study. A convenient sampling method was also applied where I only recruited participants who were easily accessible and convenient to me.

\section{Data collection methods}

The following data collection methods were used; questionnaires, interviews, drama presentation and participant observations. Participant-Observation was a special mode of observation in which I was not merely a passive observer but also a participant in the phenomenon or phenomena under study. I participated in my participants daily lives, watching what was happening, listening to what was being said, and asked questions through both formal and informal interviews, 
collecting documents and artifacts. This helped me understand various views from the participants that were not considered when drafting the questionnaires. I also applied nonparticipating observation where I used video and audio recordings to get information.

Also, questionnaires were sent to the various participants of the study; these included open ended questions which took about 1 minute per question to answer and closed ended questions. All the 40 questionnaires administered were completed and returned by the respondents. And $90 \%$ of the questions in the questionnaires were fully answered. The questions that were not attended to, participants complained that they seemed difficult to understand and there was no one to help with explanations. I distributed consent forms to my participants to ask for their permission before being part of my study, and each participant signed the consent form.

\section{Data Analysis Methods}

Data coding(identifying themes) was applied during data analysis. Data coding is a way of categorizing a text in order to establish a framework of thematic ideas about it. In coding I did not only label themes but also linked data to the key research question. I allocated codes which enabled me organize data, to examine and analyse data in a structured way. I examined relationships between the codes and then came up with the conclusion in relation to my key research question. I used words or short phrases to code the collected data, since they were easier to remember, skim, and organize. This helped me to find common themes and concepts that were linked to the research questions and then made conclusions. This was after quantifying the themes that I had obtained after coding. I applied an Inductive coding, also called open coding, which starts from scratch and creates codes based on the qualitative data itself, I didn't have a set codebook; all codes arose directly from the survey responses. I then used a flat coding frame where I assigned the same level of specificity and importance to each code. To track my codes, I used a codebook which helped me keep organized throughout the data analysis process. I used a simple Excel spreadsheet as my codebook.

\section{Demographic Information of the Respondents}

The information collected from the respondents was carefully recorded and the tables below will indicate the respondent's population or demographical information of the respondents.

Table 1: Students who pursued a Bachelors in Computer Science both male and female

\begin{tabular}{|c|c|c|c|c|c|}
\hline & $\begin{array}{c}\text { Year } \\
\text { one }\end{array}$ & $\begin{array}{c}\text { Year } \\
\text { two }\end{array}$ & $\begin{array}{c}\text { Year } \\
\text { three }\end{array}$ & $\begin{array}{c}\text { Year } \\
\text { four }\end{array}$ & Total \\
\hline Male & 2 & 1 & 3 & 3 & 9 \\
\hline Female & 1 & 1 & 4 & 5 & 11 \\
\hline Total & 3 & 2 & 7 & 8 & 20 \\
\hline
\end{tabular}

Table 2 : Students who pursued Bachelors in Divinity both male and female

\begin{tabular}{|c|c|c|c|c|c|}
\hline & Year one & Year two & $\begin{array}{c}\text { Year } \\
\text { three }\end{array}$ & $\begin{array}{c}\text { Year } \\
\text { four }\end{array}$ & Total \\
\hline Male & 2 & 1 & 2 & 4 & 9 \\
\hline Female & 2 & 2 & 3 & 4 & 11 \\
\hline Total & 4 & 3 & 8 & 9 & 20 \\
\hline
\end{tabular}

Table 3 : Students who slept on and off campus students

\begin{tabular}{|c|c|c|c|}
\hline & Off Campus & On Campus & Total \\
\hline Male & 6 & 10 & 16 \\
\hline Female & 8 & 16 & 24 \\
\hline Total & 14 & 26 & 40 \\
\hline
\end{tabular}

How university students can positively utilize technology for the growth of their spirituality.

This was the first objective of this study and the question, "How can the application of technological progress by university students be used for the good of their spiritual health"? was formulated and answered. To get answers for this question from my respondents I administered open ended questionnaires. The questions asked in the questionnaires aimed at getting a deeper understanding of the participants view in relation to the use of technology for spiritual growth, therefore the questions provided freedom for the participants to say whatever they felt. All participants answered the question, but differently as indicated in the table 4 below and this was after the analysis of all the responses from the respondents.

Table 4: Statistical responses of how technological progress can be used by university students for the growth of their spiritual health

\begin{tabular}{|c|c|}
\hline $\begin{array}{c}\text { Ways to use Technology for spiritual } \\
\text { growth }\end{array}$ & Response Percentage (\%) \\
\hline Using Bible applications on phones & 60 \\
\hline Downloading spiritual content & 20 \\
\hline $\begin{array}{c}\text { Listening to preachers and Gospel } \\
\text { Music }\end{array}$ & 10 \\
\hline Using Meditation applications & 3 \\
\hline Sharing religious information & 7 \\
\hline
\end{tabular}

Note: The responses were converted into percentages using the total number of participants.

\section{Analysis of the table}

Table 4 is showing statistical responses of 40 respondents; it indicated that all the participants strongly agreed that technological progress can be employed by university students for their spiritual growth. But the responses in the table 4 also indicated that different students used technology differently to aid their spiritual growth. In other words, every student employs a way he sees comfortable to use. As in the table 4 above, the highest number of the respondents $60 \%$ responded that they preferred using downloaded bible applications (BA) in their phones and computers. Most of these respondents 
indicated further that, these bible applications provided daily bible verse alerts thus reminding them on the practicability of the word of God. This assertion indicated that students no longer had to carry their physical bibles everywhere they went because it was provided for by technology. Therefore, technology provided easier access to the word of God.

Also, $20 \%$ of the respondents answered that they utilized technology for their spiritual growth through downloading spiritual content on the internet these included sermons by powerful preachers, hymns, theological teachings, prayers, spiritual counsellors, biblical movies etc. However, most respondents in this category pointed out that, there is a lot of scam information on the internet that may aim in luring people to satanic worship and so careful analysis of all information should be done before downloading like downloading the information from a trusted source.

Then, $10 \%$ of the respondents responded that they used technology for their spiritual growth through listening to gospel music on You Tube and great preaching from known pastors and Bishops. And, 3\% of the respondents responded that they used technology for their spiritual growth through the utilization of meditation applications which can be downloaded to one's phone or computer. One of the respondents further said that the mediations applications enabled one's mind to re-focus if at all one breaks his relationship with God. Another respondent said that mediation applications enabled him to forget other irrelevant things and think about the real reason God created him. The other respondent said that the main aim of mediation applications was to remind you the responsibility bestowed by God and start seeking the Kingdom of God.

Then, 7\% of the respondents responded that they used technology for their spiritual growth through sharing their faith and religious information on social media applications like WhatsApp, Facebook, Instagram, Twitter etc. One respondent said, every morning I post a daily devotion message in all my WhatsApp groups, this I do to remind my friends about the word of God. Another respondent said he is in four online prayer groups which includes ordained pastors who offer sermons at scheduled intervals. This clearly demonstrates the high potential of technology in the growth of university students' spiritual life.

In general, all the respondents positively agreed with the use of technology for spiritual growth and they also provided different ways of how technology can be employed if you want to develop your spirituality, however most respondents agreed that it was the bible applications in their phones and computers that helped them most to grow spiritually. Therefore, the research question one (1) was answered and the objective one (1) achieved as bible applications, spiritual content, gospel music, biblical movies and mediation applications can be used in relation to technology if one wishes to grow spiritually. The research findings therefore, show that technological progress can be used positively by university students for the growth of their spirituality. But even though most participants showed that bible applications in our phones and computers were more important for growth spiritually than other ways, I would suggest that sharing screened spiritual content using technology (WhatsApp, Facebook, Instant Messaging etc) and meditation applications like Headspace, My Affirmation, Spiritual stories daily, My phone Time, Keep Yoga, Daylio, Reiki Healing Affirmations, Insight Timer, Gaia and Jiyo. These would be very instrumental in increasing university students' participation in religious activities.

How technology impact the growth of the spiritual health of university students.

The above was the second objective of this study, and the question, "How does technology impact the growth of the spiritual health of university students? Was used to achieve the above objective. Open ended questionnaires were used to collect data to achieve objective two. The questions asked in the questionnaires and interviews aimed at getting a deeper understanding of the participants view in relation to the use of technology for spiritual growth, therefore the questions provided freedom for the participants to say whatever they felt.

Tables 5, 6, 7, 8 \& 9 below are arranged in steps onHow technology impact the growth of the spiritual health of university students? and the results are based on the respondent's responses.

Table 5: University students most locations of access to Internet for both on and off campus students

\begin{tabular}{|c|c|}
\hline Place of internet connection & Number of students \\
\hline Cyber café & 0 \\
\hline At home & 5 \\
\hline At a friend's home & 5 \\
\hline At school & 28 \\
\hline At work & 2 \\
\hline
\end{tabular}

\section{Analysis of the table:}

Table 5 showed that most students at Africa university accessed internet when they reported at school, with a total number of 28 out of 40,5 at their own homes, 5 at a friend's home, 2 at work and none used a cybercafé for connection. This therefore, means that most university students access technology fully or at its climax when they report on campus for school, meaning that's the time when their spiritual life is highly impacted by technology. Due to the fact that different places have different connection opportunities, this enables university students to recognizes such places when there; they are always using technology. But am not saying that university students should avoid such places if they are to grow spiritually. I am of a view that when in such places of high connection personal morality, self-control and self- 
discipline should be at its maximum in order to minimise the negative consequences of technology to spiritual health.

Table 6: University students' rate of using technology or how often they get connected to internet

\begin{tabular}{|c|c|}
\hline Connection rate & $\begin{array}{c}\text { Number of students } \\
(\%)\end{array}$ \\
\hline Once a month or less & 0 \\
\hline Once a week & 0 \\
\hline Several times a week & 4 \\
\hline Everyday & 10 \\
\hline The whole day 24/7 hours & 86 \\
\hline
\end{tabular}

Analysis of the table

Table 6 showed that most Africa university students accessed internet or utilized technology the whole day $24 / 7$ hours, with a percentage of $86 \%, 10 \%$ get connected at least every day, $5 \%$ get connected several times in a week, no students at Africa university goes a full week or a full month without getting connected. This means it is very difficult to separate technology with university students. Knowing the time, university students spend using a particular technology, will enable them learn how to allocate time properly for other daily life activities that may have been forgotten while using technology. In this case the time allocated for spiritual development will be thought of.

Table 7: The types of websites that are frequently visited by Africa university students when they get connected

\begin{tabular}{|c|c|}
\hline Types of Websites & $\begin{array}{c}\text { Number of } \\
\text { students (\%) }\end{array}$ \\
\hline Retail sales & 1 \\
\hline Educational or School & 54 \\
\hline Games & 10 \\
\hline Religion & 24 \\
\hline Pornographic & 11 \\
\hline
\end{tabular}

Analysis of the table

Table 7 illustrated that most students at Africa University visited educational websites like academia, Research gate, pdf drive.net, Google scholars, etc, with $54 \%$ of the respondents. $24 \%$ of the respondents responded that they visited religious websites like gotquestions.org, jw.org, bible.com, biblegateway.com etc. $11 \%$ visited pornographic websites like xvideos.com, Pornhub.com, xxnx.com, xxx.com etc. $10 \%$ visited games websites like Yahoo! Games, Y8, Pogo etc. And finally, only $1 \%$ of the respondents said they visited retail sale websites like Amzon.com, Alibaba.com, AliExpress etc. This step indicated which kind of websites university students visited frequently. Being online or using technology 24/7 hours means they are some websites that university students mostly like visiting. Knowing such websites is very important because it enables university students to do a self-evaluation of their personal lives, then do a screening of websites they visit. However, the percentage of students visiting pornographic websites is so alarming and this stands to be the greatest factor that is negatively affecting the spiritual health of university students.So, in order to be able to balance the negative and positive impact of technology on the spiritual health of university students. University students need to know which websites take plenty of their time and then act accordingly. If such websites negatively impact their spiritual health, then little attention should be given to such websites, more time be given to websites that encourage spiritual growth. This therefore, becomes step three, in the route to balance the negative and positive impacts of technology on spiritual health.

Table 8: The type of information that is frequently searched by Africa university students when they get connected to internet

\begin{tabular}{|c|c|}
\hline Types of information & Number of students (\%) \\
\hline Entertainment & 7 \\
\hline School work & 40 \\
\hline Games & 10 \\
\hline $\begin{array}{c}\text { Religion or spiritual } \\
\text { information }\end{array}$ & 30 \\
\hline Pornography & 13 \\
\hline
\end{tabular}

\section{Analysis of the table}

Table 8 indicates that most students at Africa university look for school work when they get connected to the internet with a $40 \%$ of the respondents, $30 \%$ of the respondents responded that they looked for religious or spiritual information, $7 \%$ visited internet for their own entertainment, $10 \%$ used technology for only games and finally $13 \%$ of the respondents watched pornography whenever they got connected. This step brought out the kind of information that university students are more interested when they get connected to the internet or when they use technology. And the result showed that most students searched for school work then followed by religious information every time they used technology; however, a high percentage of students were much into watching pornography and this greatly affected their spiritual health. Actually, a number of respondents proved to be addicted to watching pornography. One of the respondents recorded that he was not able to sleep if he didn't watch pornography.

Table 9 : The suggestions by respondents of how university students can balance the negative and positive impact of technology on the spiritual health

\begin{tabular}{|c|c|}
\hline $\begin{array}{c}\text { Ways to balance negative and positive } \\
\text { impact of technology. }\end{array}$ & Number of students (\%) \\
\hline Technological break & 45 \\
\hline An online spiritual platform & 32 \\
\hline $\begin{array}{c}\text { Screening websites and information from } \\
\text { the internet. }\end{array}$ & 10 \\
\hline Reducing time, you spend online & 12 \\
\hline Avoid places with unlimited wi-fi. & 1 \\
\hline
\end{tabular}




\section{Analysis of the table}

Table 9 shows the different ways of balancing the negative and positive impact of technology as suggested by the respondents; from the findings $45 \%$ of the respondents responded that taking a technological break will help to balance the impact of technology on spiritual health as one respondent said, technological break enables someone to live as a new born. $32 \%$ of the respondents suggested that an online spiritual platform could help students to balance the impacts of technology on spiritual health. Here one of the respondents reported that; the university administration or the student governing body can come up with an online spiritual platform where daily devotions, sermons, counselling session are conducted. $10 \%$ of the respondents were of the view that, screening of information got from the internet, to avoid scam information that may lead one to anti-social behaviour would enable one to balance the impacts of technology. $12 \%$ of the respondents suggested that university students need to reduce the amount of time they spent online. One respondent noted that, even if you have unlimited Wi-Fi avoid being online 24/7 hours because it is not healthy for your spiritual life, you need some time for interpersonal relationships. And only $1 \%$ of the respondents said university students needed to avoid places with unlimited Wi-Fi saying such places were provocative.To answer research question two (2) and achieve research objective (2) the question was divided into steps in order to get a comprehensive solution to the technology spirituality tension and thereafter elaborate how university students can work towards understanding how technology impacts their spiritual or religious life health.

$i$. Highly connected places. This is the first step towards understanding how technology impacts the spiritual health of university students. This looks at the locations or places where university students mostly access technology or the internet. The findings showed that most students accessed internet or used technology mostly while at school or campus. This means university students spiritual life is deemed to grow or weaken while at campus. Places of high connection either provide an arena of spiritual growth or spiritual weakening, high sensitivity while using technology is therefore required in highly connected places. It is therefore of paramount importance for every university student to know those places where he/she is always connected or in use of any kind of technology be it at school or any other place, because that is where spiritual life is highly impacted by technology. If university students identify such areas, then they will be able to monitor their spiritual life in relation to the use of technology.

ii. Connection rate.Knowing the connection rate becomes the second step in an attempt to understand how technology impacts the spiritual health of university students. The amount of time spent using technology or online by university students when in the area of high connection should be known by each and every student. The finding of the study showed that most students stayed connected 24/7 hours especially those that stayed on campus. If university students now know how much time they spend connected to the internet or using technology, they will be able to think about how much time they allocate for other activities which don't need connection.

iii. The types of websites. When using technology or when connected, what kind of websites do university students usually visit becomes the third step in an attempt to understand how technology impacts the spiritual health of university students. After knowing the places, you mostly use technology and the time you spend using technology, then you need to find out the type of websites you prefer visiting while online, are they spiritual, educative or pornographic. If they are spiritual or educative, they your spirituality is expected to grow. But if pornographic your spirituality will be affected.

The findings showed that most students visited educational websites followed by religious websites, however, a high percentage of students visited pornographic websites. The type of websites one visits defines the persons behaviours because they direct his/her thinking patterns. So, it becomes important to know the type of websites university students visit, do they link them with God or disorient them with God. Then, it will become possible to balance the impacts of such websites on spiritual health.

$i v$. The type of information. The type of information searched by university students is closely related to the type of websites visited. The change in websites visited will therefore lead to an automatic change in the information visited. Information has a great power to drive the human mind. It therefore becomes very paramount to critically screen information that is being received by university students in order to limit its negative impact.

The fourth step analysed the information that university students mostly searched for when they were connected. The findings showed that most students looked for school work followed by spiritual information, then pornographic information. But the results also showed that, the types of information searched online defined the characters of most respondents through my observation. So, to understand the impacts of technology, one also needed to be aware of the information that he mostly looks for online. This would help him/her to know how his/her spiritual health is affected.

v. Balancing technological impact.The fifth and last step looked at the different suggestions that could enable university students understand how technology impacts their spiritual health.The findings demonstrated that taking a technological break would be the best option. But also, an online spiritual platform, reducing time spent online and screening information from the internet were too important options from the respondents. However, the results showed that watching pornographic material was the leading factor that inhibited the growth of university student's spiritual life. This study will therefore suggest to look at pornography and spiritual growth as an area of further studies. 


\section{CONCLUSIONS}

The first four steps therefore, aimed at creating awareness of how university students are being affected by technology. And then, step five directly provided responses to the research question (2), the research objective (2) was therefore achieved following the five steps. Therefore, taking a technological break, and focus on life based on the laws of nature for an estimated period of time is essential as the findings showed, in an attempt tounderstand how technology impacts the spiritual health of university students. The following conclusions were made regarding research question two; highly connected places played a great role in the growth and weakening of the spiritual health of university students, this is because in such places students spent almost all their time using technology not allocating a little time for other daily religious activities that do not require technology. The type of information and websites searched or shared using technology can enable university studentsto understandhow technology impacts the spiritual health of university students. The watching of pornography by university students is the most leading factor that has led to spiritual weakening of university students.

Factors influencing university student's spiritual health as they use technology

The research question, "What factors are influencing university student's spiritual health as they use technology? Was formulated to achieve objective three. To get responses for this question from my respondents I administered open ended questionnaires. The questions asked in the questionnaires aimed at getting a deeper understanding of the participants view in relation to the use of technology for spiritual growth, therefore the questions provided freedom for the participants to say whatever they felt.

Tables 9, 10, $11 \& 12$ below will show participants response to the research question 3 .

Table 10: Statistical responses of ways how technology denies university students God's Grace

\begin{tabular}{|c|c|}
\hline Ways technology denies God's Grace & $\begin{array}{c}\text { Percentage Response } \\
(\%)\end{array}$ \\
\hline Misleading information & 49 \\
\hline Distractions & 23.5 \\
\hline Time consuming & 7 \\
\hline Advertisements & 7.5 \\
\hline Distorts human relationships & 5 \\
\hline Watching Pornography & 8 \\
\hline
\end{tabular}

Analysis of the table

Table 10 shows that misleading information from the internet or information made available by technology was the greatest factor that could deny university students God's grace as indicted by $49 \%$ of the respondents. One of the respondents is recorded to have said that some students end up joining satanic groups because of promised success from the internet information. $23.5 \%$ of the respondents were of the view that distractions caused by technology denied university students from achieving God's grace. As one of the respondents said, most students miss Sunday services and even some other scheduled prayer sessions because of certain movies especially Serie movies.

Then, $7 \%$ of the respondents said that technology took most of their time, which at least could have been used to create a proper relationship with God. $7.5 \%$ of the respondents said that the advertisements that kept popping up while in use of technology were too attractive and mind changing. 5\% of the respondents said that technology distorted interpersonal relationship. As one of the respondents said, most students feel tiresome to even go next door to greet a friend and just prefer texting, thus avoiding face to face contact. This has led to virtual friendship, thus loosing value relationships with people near them.

And finally, $8 \%$ of the respondents, reported that their spiritual health was mostly affected through watching pornography. One of the respondents is noted to have said that, every time he was in the room alone, he could always watch pornography and the end result of watching pornography was masturbation. Watching pornography was more made available by the unlimited and unrestricted Wi-Fi on campus, which leads to some university students miss organised church services. These factors put together, prevented university students from accessing God's grace, but if realised and worked upon then technology can support the attainment of God's grace.

Table 11: Statistical responses of ways how technology can be channelled by university students as a support of God's Grace

\begin{tabular}{|c|c|}
\hline Ways technology supports God's Grace & $\begin{array}{c}\text { Percentage Response } \\
(\%)\end{array}$ \\
\hline Research about spiritual information & 14 \\
\hline Sharing spiritual content & 64 \\
\hline Listening to sermons and gospel music & 13.5 \\
\hline Meditation programmes & 3.5 \\
\hline Setting alerts for prayers & 5 \\
\hline
\end{tabular}

\section{Analysis of the table}

If university students become aware of the negative impact of technology and work upon them, then technology could be used to support their attainment of God's grace. Table 11 shows the findings from the respondents on how technology could support God's grace. The findings showed that sharing spiritual content (SSC) using that technology was the most effective factor that helped university students grow spiritually. Actually, $64 \%$ of the respondents indicated that they at least received a daily devotion in their church and fellowship WhatsApp groups each and every morning. 14\% of the respondents said that, they used technology to research about spiritual information especially through bible commentaries, asking spiritual questions and that the scripture was brought closer to them. One respondent is noted to have 
said that, he gave his hard copy bible to her mother ever since she bought a smart phone. $13.5 \%$ of the respondents said they grew spiritually using technology through listening to sermons and gospel music from YouTube. And due to the fact, that, Wi-Fi on campus was unlimited and unrestricted this presented a greater opportunity to download plenty of spiritual information from YouTube. A smaller number of respondents said they used meditation applications, which $3.5 \%$ of the respondents. And finally, $5 \%$ of the respondents said technology helped them to set prayer time alerts.

This meant that technology could totally be used as an instrument to achieve God's grace. Through the different ways as indicated in the table above university students could achieve God's kingdom with maximum ease through utilization of technology. If only university students concentrated on the five listed factors in the table above; sharing spiritual content, listening to gospel music and watching biblical movies, researching about spiritual information, using mediation application and setting alerts for prayer times, bible verse alerts, the kingdom of God would readily available for university students.

Table 12: University students' opinions on the rejection or adoption of technology for spiritual growth

\begin{tabular}{|c|c|}
\hline & Percentage Response (\%) \\
\hline Rejected & 2.8 \\
\hline Adopt & 97 \\
\hline None/ Undecided & 0.2 \\
\hline
\end{tabular}

\section{Analysis of the table}

The overall findings showed that $97 \%$ of the respondents opted to adopt technology as an instrument that can be channelled and applied for spiritual growth thus enabling in the attainment of God's grace. In other words, there was no option of rejecting technology, because it presented a lot of positive contributions to the growth of university students spiritual health. In fact, the findings showed that it was easier to adopt technology that rejecting it, especially when you look at the current modernity in the universe, where people have a slogan that, "time is money" or "time wasted is never regained". Technology is making all aspects of life easier and brought a lot out of poverty. So, if God is for the poor and technology can make life easier for the poor, then rejecting it would indeed become a mystery, "what then is needed"? The only answer to this question is adoption.

However, people have to be taught on how to utilize technology for the good of their spiritual health. Educative measures need to be put into place to aid university students in the use of technology, such that it can perform it's intended task (Borgmann, 2014). This means that technology could work in service of spiritual health thus becoming a servant of spiritual health and not a master of spiritual health that could dictate spiritual matters.
Table 12 also shows that, only 3\% of the respondents disagreed with the utilization of technology for spiritual growth rendering it a master of spiritual health that should be totally rejected if at all one wanted to pursue God's kingdom. In my analysis of the responses of this group, technology was compared to a "serial killer" raiding the human soul, so, the call was to everyone to wake up and fight this enemy. Technology was likened to a destroyer of human spirituality. $0.2 \%$ of the respondents were didn't take sides, or they took the middle ground. These were not able to distinguish either technology could be used for spiritual growth or not.

\section{DISCUSSION AND INTERPRETATION}

After the analysis of all responses from the three research questions, the research findings indicated that; first, technological progress can be used positively to develop the spiritual health of university students, second, it is very possible to balance the negative and positive impact of technology on the spiritual health of university students and third, technology can be used as a support of God's grace, therefore it cannot be rejected but adopted. And watching pornographic material was the main limiting factor of the spiritual growth of university students and it requires great attention, if at all technology is to be taken as an ally of spiritual health to university students. The findings particularly indicated that, through the use bible applications in phones and computers, sharing of spiritual content, using mediation applications, university students could grow spiritually. Therefore, technology is of much importance in the growth of the spiritual health of university students and the community at large. However, the use of technology for spiritual growth differed from student to students as each student preferred to use a way which was more comfortable and convenient to him/her. This is was due to preference, familiarity, financial requirements and accessibility factors.

But the above findings did not mean that technology could not limit spiritual growth. A less percentage of the respondents showed less interest in the use of technology for any spiritual issue as they dubbed it an enemy of spiritual health. As Christian (2012) says, technology changes the way we think about life and ourselves to an abbreviated way which focuses only on our personal agendas, it makes people greedier with less care of others. This is totally against the will of God and it denies God's grace. Technology is capable of completely changing the total personality of a person to a new outlook, because it is able to control our minds through the information it provides, thus affecting our decision making.The decisions making process can be affected in two ways; you either make decisions that will lead you to God's kingdom or decisions that will lead you away from God's kingdom.

From my own point of view, technology should be seen as a man's invention using the knowledge from God to simplify man's task of praising God, the worship of God included. This means that if man needed something that could ease the way to the Kingdom of God, technology was the first priority because it has all what it takes to aid spiritual growth. As 
Borgmann (2014) says, technology is more of an ally to spirituality than a foe, so it must be utilized for the growth of our spirituality. Rosie (2014) stated that, humans were created to be stewards of the universe, and in dominion of everything on earth. This includes technology which is a human invention. We should therefore desist from allowing technology to dominate and control humanity. Everything in the universe is very capable of assisting man to attain God's grace and technology is one of those things. It is therefore high time, we utilized technology for its rightful purpose, for I see it as an instrument for the attainment of God's grace by humanity. The reason why God made man in his image was that humanity reflects the wisdom of God and His rationality. God then gave humanity brains to be creative, and live a Godly life. So, everything that is invented by man should be a drive towards living a Godly life. But the dissatisfaction of some people and the want for more, has led to the misuse of technology thus labelling it an enemy of spirituality.

Even though it would be an exaggeration to proclaim technology having a sole role of helping humanity to attain God's kingdom, especially looking at the negative connotations it has presented to the spiritual health of university students, deeming it very risky to their spiritual health. I do not buy the idea that it should be rejected and not be used for spiritual growth. "God is nothing else but this marvellous universe which follows its own scientific laws. Spirituality is nothing else but understanding ourselves and the laws of the universe through the tools of science and technology" says (Rajvanshi, 2018). That quotation from Rajvanshi means technology and spirituality can actually work hand in hand, each influencing the other. I will use a metaphor of two children with the same father but different mother to relate technology and spirituality. Both technology and spirituality have the same father; that's God but while technology has its mother as humanity, spirituality has its mother as God. Now, this means there is a blood relation between technology and spirituality that cannot be broken especially in this 21 st century. Also, even though at times family members disagree, there is a time to sit at length and talk about the differences, but division becomes a least option. And also, family members unite when an enemy invades, this means working hand in hand. So, whereas technology can increase ones' spirituality, spirituality too can develop technology and most importantly in its favour. Educative measures therefore, need to be put in place for the be better utilization of technology, because rejection is not an option.

The findings also showed that it was very possible to balance the negative and positive impact of technology, and this could result in the growth of the spiritual health of university students. Becoming aware of the negative impact of technology to ones' spiritual life would play a bigger role in trying to balance the negative and positive impact of technology. The following steps would be very helpful; first is being aware of how you are using technology in relations to the growth of your spirituality, this can be through identifying the places where you are mostly connected, websites and information you visit, then start screening such information. Second is to breath and calm down and then think about how your use of technology has impacted you spiritually. Third you now need to make a choice, if your spiritual health has been impacted positively you continue the same routine, but if you have been impacted negatively then act otherwise. The last and fourth step is to start doing whatever you have decided, execute your choices. I will term this as ABCD formula.

ABCD represents the four steps that university students and the community at large would practise in order to balance the negative and positive impact of technology on their spiritual health. A, stands for awareness of how you are using technology, B, stands for breath, you relax and think how you are being affected, $\mathrm{C}$, stands for choice, you decide on what to do next, and D, stand for doing, practising or executing your choices.

Taking a technological break was agreed upon by a majority of respondents as one way that could help university students to balance the negative and positive impact of technology on their spiritual health. Taking a break would not mean to abandon the use of technology, but each student would be required to set up a time in a day, a week or a month, when he can live as if there was no technology in the world reflectively. This would require that student to live an oldfashioned way of life following the laws of nature. Heschel (1951) suggested the term, "technology sabbath", which meant creating for yourself a holy day just like the sabbath is holy. On this day you would concentrate on the praise of God, strengthening interpersonal relationship and living according to the dictates of nature.

The findings showed that it was very possible to take a time off technology and live as if it was the 17th century. With this possible it will enable many university students to revise behaviours in regard to their relationship with God and the interpersonal relationships. A techno spiritual retreat will enable university students refocus their mindsets back to the focal principles of God. They would be able to realize a lost adventure before the invention of technology. This revisiting of the old life will enable university students realize that they have been driven away from real essence of life that was intended by God. After realizing that reality then technology and spirituality can work together. However, technology has become too much of a necessity that taking a "techno retreat" might not be a solution. Many churches, businesses and programs have gone totally online, to the extent that staying a minute offline will be a great lose. So other options need to be looked at, that will enable, the use of technology while growing spiritually, that's why I had to develop Heschel's model of technology sabbath.

The findings also showed that, technology does not deny university students God's grace, but in the other way round, it can be channelled as a support of God's grace by university students. This simply means there is no need to reject technology. Indick (2012) suggests, messaging and texting of 
spiritual information, biblical videos from the internet and vast number of commentaries online as some of the resources that would increase the spirituality of university students, if at all they were used with discipline. This therefore means that, people need to adopt the evolving technology and stop thinking of rejecting it, because has technology came to stay. As Banks (2016) stated, technology has come to stay, and it won't stop anytime soon. I would like to liken technology to a brainchild, a parent gives birth to a child and when that child grows up, it means the parent might not be able to control the child fully because of the requirements of an adult, but that does not mean the child has stopped being the child and the parent has stopped being the parent. The parent still has that respect of being a parent, and has full rights to discipline his child even when he is an adult. This is what has happened between technology and humanity, the child, "technology" has disobeyed the parent, "humanity". But the parent reserving that respect of being a parent, can still call the child to discipline, if he notices that the child is going astray. So, humanity as the parent of technology are to act as parents and sanitise the use of technology, such that it positively contributes to the growth of the spiritual health of university students and the community at large. It is also very important to note that, self-discipline and self-control are two highly demanded qualities when using technology if it is to benefit one's spiritual health. Misleading information and watching pornographic material being the main hinderances to spiritual growth while using technology as per the findings. Careful analysis of any information should be done before being shared to anyone on WhatsApp groups, as sharing spiritual information comes out on top as way that could strongly support spiritual growth using technology.

Technology can therefore not be rejected in any case because it possesses the potential to lead university students and the community at large into the Kingdom of God if properly utilized. As the findings indicated, university students need to continue embracing technology but critically monitor how it impacts their spiritual life. The availability of online platforms in form of websites that provide a variety of spiritual support and content like downloadable sermons, gospel music, spiritual counselling services, meditation services, and online church services have brought the church very close to the community than ever before. Even in a car or a plane travelling one is able to attend a church service. In periods of national disasters when religious gatherings are prohibited and religious building closed like the case of Corona Virus (COVID-19). Technology has stood up to cover the gap. Why now can't it enable spiritual growth. Gone are the days, when people move around with bible hard copies and in one version (Thoreau, 2000). Now people, are able to download a full packaged bible application with all versions, no longer to base on the same hard copy you possessed. The word of God has been brought on the fingertips of every Christian through our phones and computers by technology.

This is therefore, enough to support the assertions that with technology we have gotten ourselves an easier route to heaven. God has provided us with an easier way to reach heaven through the use of technology. But unfortunately, many of us have not realised this possibility. We are instead using technology for our own greedy agendas leading us into satanic worship. University students, having a high access to internet and technology are to take this opportunity to earn heaven for themselves, by using technology in a way that strengthens their relationship with God. That's if the Christian teachings about heaven or the kingdom of God are true.

\section{Model for technology use}

As noted in my theoretic frame work, Abraham Joshua Heschel, proposed the Technology Sabbath, in his article, "the Sabath" written in 1951, as one procedure individuals could rightly use to limit the impact of technology on their spiritual life. As the Christian Sabbath proposes, Heschel's model also proposes for people to give up all technological related activities and live according to the rules of nature except for urgent activities. After analysing Heschel's model I found it a bit old, not contextual and lacking key elements relevant to the development of spiritual life and proper use of technology. I then made it a task to develop Heschel's model and add on key valuables that I think would make it relevant and finally develop a new model that individuals could utilize as they use technology.

I came up with a model of how university students and the community at large would be able to use technology for the growth of their spirituality and also be a ble to contend the "technology spirituality tension" (TST). This model of technological use combines a, "techno spiritual retreat" (TSR) which Heschel called the technology sabbath and the, "Awareness, Breathe, Choice and Doing" ABCD formula. Techno spiritual retreat (TSR) is to take a time off without using technology and then refocus on the life without technology and make comparisons and reflections on your life experiences while using technology and how it affects you. The TSR is very important because it gives birth to the ABCD formula, it is also, very paramount because it encourages to do a self-reflection and self-evaluation regarding your technological use patterns which is very difficult to do while connected or online. Now the main focus of the TSR is to reflect on your relationship with God, in other words to reflect on the growth patterns of your spirituality in relation to use of technology. This stage shouldn't take a long time because to some people technology is a necessity. But it can depend on everyone's ability to stay without using technology.

The next step after a TSR is to apply the Awareness, Breathe, Choice and Doing or ABCD formula. The ABCD formula is an addition to the technological spiritual retreat, formerly technology Sabbath, which I saw insufficient to enable proper use of technology by university students. The ABCD formula doesn't prevent you from using your technology, but it can be applied while utilizing your technological gadgets. Its main focus is to create awareness of how the spiritual health of an individual is affected by technology either positively or negatively and then respond in accordance to the awareness. 
The application of all the four steps enables individuals to use technology for the growth of their spiritual health. The ABCD formula is also aimed at putting technology in services of spiritual health and this is how it works towards making technology a hand maid of spiritual health. It first makes you aware of how your spiritual health is being affected by technology, when you become aware of how you are being affected. You then take the necessary steps, but do not rush to act, first breathe, calm down and relax before making your choice. Many people make choice and fail to execute them, if you do not do or practise your choice the formula will not work. After applying this model of technological use; technology will be considered an instrument of God's grace.

I replaced the statement, "technology Sabbath" by Heschel with, "technology spiritual retreat" for I think it is not completely giving up on technology use, but just taking some time off, to reflect on how you are using technology and how it is affecting you then come up with a new procedure of using technology. Technology Sabbath seems to mean you just rest of all technological activities, it does not bring in the reflective aspect, which I think the technology spiritual retreat does. The ABCD formula is just a developmental addition to the technology spiritual retreat to cater for the reflective part of the of the major model.

However, am not of the view that this formula is perfect and can work out in all cases, this is my personal build up or idea in an attempt to help contend the technology spirituality tension (TST). For I believe technology has the potential to develop our spirituality. People are free to use any other methods that they feel can help set them free from the dependence, addiction or enslavement of technology for them to benefit spiritually.

\section{CONCLUSIONS}

After the presentation and analysis of the gathered data I concluded that; Technological progress can be used by university students to aid their spiritual growth. This is because the findings showed that technology provided an easier access to spiritual information through online platforms like religious websites, downloadable bible applications, downloadable sermons on YouTube etc. However, the ability of technology to aid spiritual growth of university students is not a guarantee, but proper utilization coupled with selfreflection and self-evaluation while using technology is highly recommended. This is because if technology is used in a wrong way, it is very capable of weakening one's spirituality thus breaking one's relationship with God.

University students were capable of balancing the negative and positive impact of technology on their spiritual health. This is so because from the findings it showed that technology had more positive impact to spiritual health as compared to the negative impact. So, university students are to embrace technology as an aid to the growth of their spiritual life. But great self-discipline, personal morality and self-control is highly demanded while using technology.
Technology cannot deny university students the grace of God, but it could rather be used as a support of God's grace. This is so because the gathered data showed that, technology brought the word of God and the church closer to people than ever before. This is through the presentation of high-level spiritual support through its online platform services, which include online churches. Technology proved the most effective instrument that could bring university students closer to God. The research findings therefore demonstrate the need to apply technology by university students in their need to grow spiritually. Watching pornography is a key factor in weakening the spiritual health of university students. This is so because the gathered data, presented a high percentage of students who were addicted to watching pornography and most of the respondents confessed that it prevented them from reaching out to religious resources while they utilized technology.

\section{REFERENCES}

[1] Allen, M ( $7^{\text {th }}$, November, 2019) Technological Influence on Society Alvernia University, https://www.bctv.org/2019/11/07/technological-influence-onsociety/

[2] Banks, R. (1983). The Tyranny of Time. Downers Grove. IL: InterVarsity Press.

[3] Barna Group (2016, June, 15 ${ }^{\text {th }}$ ) "The State of the Bible: 6-year trends." Retrieved from https://www.barna.com/research/thebible-in-america-6-year-trends/.

[4] Behav, A (28th, February, 2017) The Internet's effect on personality traits: An important casualty of the "Internet addiction" paradigm doi: 10.1556/2006.6.2017.009

[5] Borgmann, A. (1993), Crossing the Postmodern Divide. Chicago: The University of Chicago Press.

[6] Borgmann, A. (2003), Christianity in the Culture of Technology, Power Failure. Grand Rapids: Brazos Press.

[7] Borgmann, A. (2014). Technology and the Character of Contemporary Life, A philosophical Inquiry. Chicago: The University of Chicago Press.

[8] Buckingham, D., \&Domaille, K. (2002) “Where Are We Going and How Can We Get There? General findings from the UNESCO Youth and Media Education Survey. Retrieved from http://lnnk.in/bEce

[9] Carr, N. (2010) The Shallows: What the Internet is Doing to Our Brains. New York, W.W.

[10] Christian, A. B. (2012). The church in the contemporary world: information and communication technology in church communication for growth. Chicago: The University of Chicago Press.

[11] Darius, K. S. C., \& Grand H. L. C. (2004) “A Comparison of Offline and Online

[12] David, A. (2001), "A Spirituality for Sustainability: Partnership with Nature and God", http://www.ncrlc.com/ncrlc-RPwebpages/spiritualsustainability.html.

[13] Ellul, J. (1997) The Meaning of the City. Grand Rapids, Carlisle, UK: Paternoster.

[14] Emoavwodua, J ( ${ }^{\text {th }}$, January, 2018) See How Technology is Taking Over Our Life's, John,https://thriveglobal.com/stories/ifyou-think-technology-is-not-taking-over-everything-we-do-thenread-this/

[15] Friendship Qualities at Different Stages of Relationship Development," Journal of Social 21(3), 305-320 retrieved from https://journals.sagepub.com/doi/10.1177/0265407504042834

[16] Geneva business school $\left(10^{\text {th }}\right.$, August, 2020) 5 ways technology has made us lazy; Has technology has made us complacent, or simply relieved us of our chores? Let's look at five ways technology is making us lazy, 
https://gbsge.com/en/news/newsroom/newsroom/5-waystechnology-has-made-us-lazy/

[17] Gigli, T \& Genova, A (2001) Young People and Media in Central \& Eastern Europe, the CIS \& Baltic States, A report prepared by InterMedia for UNICEF

[18] Indick, W. (2012). The Digital God; How technology will reshape spirituality. USA: Jefferson, North Carolina McFarland \& Company, Inc., Publishers.

[19] Jechoutek, K. G. (2004), "Through the Eye of the Needle: Tradition, Spirituality and Human Development", Humanity in Science and Religion: the South African Experience, retrieved from http://info.worldbank.org/etools/library/latestversion.asp?137722.

[20] Leah, M (9 $9^{\text {th }}$, February, 2018) 3 Ways Technology is Hurting the Faith of Children and Teens; Technology can do a world of good yet it can also hurt the spiritual walk of children and adolescents today, https://www.christianpost.com/branded/3-ways-technologyis-hurting-the-faith-of-children-and-teens.html

[21] Legg, T (25 , February, 2020) Negative effects of technology: What to know, https://www.medicalnewstoday.com/articles/negative-effects-oftechnology

[22] Lybi, M (27 ${ }^{\mathrm{TH}}$ July, 2011) Technology: Is Technology Stealing Our (Self) Identities? Who or what is defining your selfidentity? Reviewed by

Lybi

Mahttps://www.psychologytoday.com/us/blog/the-powerprime/201107/technology-is-technology-stealing-our-selfidentities
[23] Makayla, C. S. (1996) Iowa Journal of Cultural Studies, Home Alone with Technology: An Interview with Neil Postman, (15) 27. Retrieved from https://ir.uiowa.edu/ijcs.

[24] Narasimhananda, S. (2015, November, 5th). Spirituality and Technology. Prabuddah Bharata. Retrieved from https://www.esamskriti.com/e/Spirituality/Philosophy/Spiritualityand-Technology-1.aspx

[25] Neil, P. (1992) Technopoly: The Surrender of Culture to Technology. New York: Vintage Press.

[26] Olthuis, J. H., Marshall, P., Griffioen, S., \& Mouw. R. (2011). 'On Worldviews', Stained Glass World Views and Social Science, (eds). New York: University Press of America.

[27] Rajvanshi. (2016, July, 15 ${ }^{\text {th }}$ ) How technology and spirituality together hold the secret to happiness. (Blog post) retrieved from https://www.huffingtonpost.in/dr-anil-k-rajvanshi/spiritualitytechnology-h_b_6409222.html

[28] Steinhart, E (27 ${ }^{\text {th }}$, September, 2018) Technology and Spirituality https://www.snsociety.org/technology-and-spirituality/

[29] Thoreau, H. D. (2002) Walden and other writings. New York: Random House.

[30] Tom, H., \& Nita, H. (2010). Forbidden gates; the dawn of technodimensional spiritual welfare. USA; Crane, Missouri Press.

[31] Wendell, B. (2002). The Art of The Common Place. Berkeley: Counterpoint Press.

[32] Wenger, E. C. (2016). Communities of practice: learning, meaning and identity. England: Cambridge University Press. 